https://www.journal-imab-bg.org

Review article
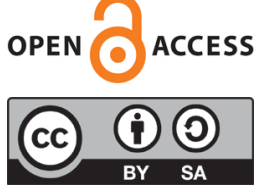

\title{
DENTAL CONSIDERATIONS IN PATIENTS TAKING NEW ANTIPLATELET AND ANTICOAGULANT DRUGS
}

\author{
Atanaska S. Dinkova ${ }^{1}$, Hristo I. Daskalov ${ }^{1}$, Delian Delev ${ }^{2}$ \\ 1) Department of Oral Surgery, Faculty of Dental Medicine, Medical University \\ of Plovdiv, Bulgaria \\ 2) Department of Pharmacology and Clinical Pharmacology, Medical University \\ of Plovdiv, Bulgaria.
}

\begin{abstract}
Atherosclerosis and the resulting cardiovascular and cerebrovascular diseases (myocardial infarction, coronary artery disease and stroke) are the leading cause of mortality and morbidity in the developed countries. Worldwide, over 10 million deaths per annum are caused by arterial thrombosis (ischaemic stroke, heart disease, peripheral gangrene).

Leading in the treatment and prevention of thrombotic complications are the anticoagulant and antiplatelet drugs which are taken by millions of patients worldwide.

A review of the literature shows that clinical trials involving dental extractions in patients taking antithrombotic drugs have been conducted for more than 50 years and are still ongoing.

Recently, new antiplatelet and anticoagulant drugs: direct thrombin inhibitors, factor $\mathrm{Xa}$ inhibitors and a new class of oral thienopyridines (inhibitors of Glycoprotein IIb/ IIIa and P2Y12 receptors) have been introduced on the market and are becoming increasingly common. The implications of these drugs during dental treatment are not yet known, and there is not enough information available within the literature on safe use during dental surgery. The purpose of the present review is to discuss the pharmacological properties of the new antiplatelet and anticoagulant drugs, their usage in the perioperative setting, and some guidance for dental practitioners performing invasive dental procedures.
\end{abstract}

Keywords: haemostasis alteration, blood coagulation disorders, new antiplatelet drugs, dental management antiplatelet, oral surgery, NOA, thrombosis.

\section{INTRODUCTION}

With prolonged life expectancy, the number of elderly patients requiring dental treatment increases. These patients often are with chronic diseases, treated with multiple medications. The leading cause of mortality and disability in the world are cardiovascular and cerebrovascular diseases. The cardiovascular diseases annually cause nearly one-third of the planet's mortality, 47 percent of mortality in Europe and over 60 percent in Bulgaria. Lead- ing in the treatment of these diseases and the prevention of their complications are the antithrombotic medications, which application grows at an annual rate above $10 \%$ [1].

Arterial and venous thrombosis has an important impact on worldwide morbidity and mortality. Worldwide over 10 million deaths per annum are caused by arterial thrombi, resulting in ischaemic stroke, heart disease or peripheral gangrene.

Platelets are the key pro-thrombotic element in the arterial thrombosis, forming aggregates interconnected by fibrin, thus antiplatelet drugs are leading in the treatment of arterial thrombosis. Half a million deaths related to venous thromboembolism occur in the European Union per year [2]. Venous thrombi consist mainly of fibrin with few cells in between. Anticoagulants are the drugs of choice to prevent or treat these conditions [2].

Three main classes of antiplatelet agents are licensed for the treatment of atherothrombosis: acetylsalicylic acid (aspirin), P2Y12 inhibitors (ticlopidine, clopidogrel, prasugrel, cangrelor, ticagrelor), and GpIIb/IIIa receptor antagonists (abciximab, eptifibatide, and tirofiban). While the latter have intravenous administration in ACS in combination with other antithrombotic agents (their effect being unpredictable when administered orally), the former two classes are widely used chronically [3].

\section{NEW ÀNTIPLATELET ÀGENTS}

The clinical efficacy of aspirin, ticlopidine, and clopidogrel is only partial because they inhibit TXA2-mediated or ADP-mediated platelet aggregation, leaving the activity of other platelet agonists such as thrombin largely unaffected. Another drawback is the high inter-individual variability in platelet inhibition by clopidogrel, which is attributed to differences in the extent of clopidogrel prodrug metabolism. Clinical, cellular and genetic factors have been associated with clopidogrel resistance. This variability is clinically important since many studies have demonstrated that patients exhibiting high on-treatment platelet reactivity (clopidogrel resistance or hyporesponsiveness) are not adequately protected from major adverse cardiac events. It is estimated that approximately one-third 
of clopidogrel-treated patients exhibit a diminished ex vivo platelet response to clopidogrel [4].

Ticlopidine, clopidogrel, prasugrel, and ticagrelor are approved P2Y12 antagonists, whereas cangrelor is still in clinical development. Ticlopidine is not frequently prescribed, owing to its unfavourable safety profile; whereas clopidogrel is the most widely used P2Y12 inhibitor. Prasugrel and ticagrelor are novel P2Y12 receptor inhibitors. Prasugrel acts as an irreversible oral inhibitor of the P2Y12 receptor. Ticagrelor, a cyclopentyl-triazolo-pyrimidine, is the first orally available reversible antagonist of the P2Y12 receptor (Table 1) [5].

\begin{tabular}{|c|c|c|c|c|c|c|c|}
\hline Class & $\begin{array}{l}\text { Mechanism of } \\
\text { action }\end{array}$ & Drug & $\begin{array}{l}\text { Time to reach a } \\
\text { peak plasma } \\
\text { concentration }\end{array}$ & $\begin{array}{l}\text { Metabolism } \\
\text { to active } \\
\text { metabolite }\end{array}$ & $\begin{array}{l}\text { Route of } \\
\text { elimination }\end{array}$ & $\begin{array}{l}\text { Elimination } \\
\text { half-life }\end{array}$ & $\begin{array}{l}\text { Time required } \\
\text { to restore pla- } \\
\text { telet function }\end{array}$ \\
\hline $\begin{array}{l}\text { Salicylates (COX } \\
\text { inhibitors) }\end{array}$ & $\begin{array}{c}\text { Inhibition of } \\
\text { cyclooxygenase }\end{array}$ & $\begin{array}{l}\text { Acetylsalicylic acid, } \\
\text { Aloxipyrine, Carba- } \\
\text { salate calcium, } \\
\text { Indufene, Triflusal } \\
\text { Abciximab }\end{array}$ & $30-40$ minutes & No & $\begin{array}{c}\text { Liver by } \\
\text { deacetylation to } \\
\text { salicylic acid }\end{array}$ & $\begin{array}{c}\text { Irreplaceable } \\
\text { inhibition of } \\
\text { platelets }\end{array}$ & $30 \%$ on the $48 \mathrm{~h}$ \\
\hline \multirow{5}{*}{$\begin{array}{l}\text { Glycoprotein Ilb / } \\
\text { Illa antagonists }\end{array}$} & & $\begin{array}{c}\text { (ReoPro)monoclonal } \\
\text { antibody 7E3 (c7E3 } \\
\text { Fab) i.v. }\end{array}$ & $10-30 \mathrm{~min}$ & No & $\begin{array}{l}\text { Degradation by } \\
\text { proteolysis in the } \\
\text { kidney }\end{array}$ & $10-30 \mathrm{~min}$ & $48 \mathrm{~h}$ \\
\hline & $\begin{array}{l}\text { Reversibly binding } \\
\text { to the platelet } \\
\text { receptor glycopro- } \\
\text { tein (GP) IIb/llla }\end{array}$ & $\begin{array}{l}\text { Eptifibatide } \\
\text { (Integrilini.v. }\end{array}$ & & No & $\begin{array}{c}\text { renal excretion } \\
(98 \%) .\end{array}$ & $2,5 \mathrm{~h}$ & $4 \mathrm{~h}$ \\
\hline & & $\begin{array}{c}\text { Tirofiban (Aggrastat) } \\
\text { i.v. }\end{array}$ & & No & $\begin{array}{l}\text { Urine }(65 \%) ; \\
\text { feces }(25 \%)\end{array}$ & $2 \mathrm{~h}$ & $4-8 \mathrm{~h}$ \\
\hline & $\begin{array}{l}\text { Platelets glycopro- } \\
\text { tein (GP) Ilb/llla } \\
\text { antagonist }\end{array}$ & Roxifiban p.o. & & Yes & & & \\
\hline & $\begin{array}{l}\text { Platelets glycopro- } \\
\text { tein (GP) Ilb/llla } \\
\text { antagonist }\end{array}$ & Orbofiban p.o. & & & & $18 \mathrm{~h}$ & \\
\hline \multirow[t]{3}{*}{ Thienopyridines } & $\begin{array}{l}\text { P2Y12 reversible } \\
\text { receptor inhibition }\end{array}$ & Clopidogrel p.o. & $\begin{array}{l}2-4 \text { hours } \\
(300 \mathrm{mg} .)\end{array}$ & Yes & $\begin{array}{l}\text { Liver through a 2- } \\
\text { step process } \\
\text { involving } \\
\text { CYP3A5 / } \\
\text { 2CD19 to an } \\
\text { active metabolite }\end{array}$ & $6-8$ hours & $\begin{array}{c}5-7 \text { days ( } 40 \% \\
\text { on } 3 \text { days) }\end{array}$ \\
\hline & $\begin{array}{l}\text { P2Y12 reversible } \\
\text { receptor inhibition }\end{array}$ & Ticlopidine p.o. & 2 hours & Yes & \begin{tabular}{|c} 
Liver \\
CYP2CD19 to an \\
active metabolite
\end{tabular} & 12 hours & $\begin{array}{l}12 \text { hours (single } \\
\text { dose) } 4-5 \text { days } \\
\text { (multiple intake) }\end{array}$ \\
\hline & $\begin{array}{l}\text { P2Y12 reversible } \\
\text { receptor inhibition }\end{array}$ & Prasugrel p.o. & $\begin{array}{l}1-2 \text { hours } \\
\text { (60 mg.) }\end{array}$ & $\begin{array}{c}\text { Metabolite (R- } \\
\text { 138727) }\end{array}$ & \begin{tabular}{|c|} 
Liver \\
CYP2CD19 to an \\
active metabolite
\end{tabular} & $2-15 h$ & 2 weeks \\
\hline Sulphonylurea & $\begin{array}{l}\text { P2Y12 reversible } \\
\text { receptor inhibition }\end{array}$ & Elinogrel p.o. i.v. & $20 \mathrm{~min}$ & No & Liver and kidney & No & $\begin{array}{l}8 \text { hours after } \\
\text { single dose of } 10 \\
\text { mg: longer at } \\
\text { high dose (-1 } \\
\text { day) }\end{array}$ \\
\hline ADP-analogue & $\begin{array}{l}\text { P2Y12 irreversible } \\
\text { receptor inhibition }\end{array}$ & Cangrelor i.v. & $3-9 \min$ & No & $\begin{array}{l}\text { Liver }(58 \%) \text { and } \\
\text { kidney }(35 \%)\end{array}$ & minutes & $1-2 \mathrm{~h}$ \\
\hline $\begin{array}{c}\text { Cyclopentyl- } \\
\text { triazolopyrimidine }\end{array}$ & $\begin{array}{l}\text { P2Y12 irreversible } \\
\text { receptor inhibition }\end{array}$ & Ticagrelor p.o. & $1,5-3$ hours & No & $\begin{array}{l}\text { Liver to an active } \\
\text { metabolite }\end{array}$ & $6-12$ hours & 5 days \\
\hline $\begin{array}{l}\text { Phosphodieste- } \\
\text { rase inhibitor }\end{array}$ & $\begin{array}{l}\text { Inhibition of phos- } \\
\text { phodiesterase }\end{array}$ & Dipyridamole p.o. & $75 \mathrm{~min}$ & No & $\begin{array}{l}\text { Liver glucoro- } \\
\text { nidation to an } \\
\text { active metabolite }\end{array}$ & 10 hours & 2 days (?) \\
\hline $\begin{array}{l}\text { Phosphodieste- } \\
\text { rase III inhibitor }\end{array}$ & $\begin{array}{l}\text { selective inhibitor of } \\
\text { phosphodiesterase } \\
\text { type III }\end{array}$ & $\begin{array}{l}\text { Cilostazol p.o. } \\
\text { twice-daily }\end{array}$ & - & No & $\begin{array}{l}\text { Liver CYP3A4/ } \\
\text { 2CD19. To } \\
\text { active metabolite }\end{array}$ & $11-13$ hours & 2 days (?) \\
\hline
\end{tabular}




\begin{tabular}{|c|c|c|c|c|c|c|c|}
\hline $\begin{array}{c}\text { TP-receptor } \\
\text { antagonist }\end{array}$ & $\begin{array}{c}\text { PAR-1 Inhibition } \\
\text { selective thrombo- } \\
\text { xane prostanoid } \\
\text { (TP) antagonist }\end{array}$ & $\begin{array}{c}\text { Terutroban (S18886) } \\
\text { p.0. }\end{array}$ & 30 min-2 hours & No & $?$ & 6-10 hours & $?$ \\
\hline $\begin{array}{c}\text { PAR-1 receptor } \\
\text { inhibitor derived } \\
\text { from the natural } \\
\text { product } \\
\text { himbacine }\end{array}$ & PAR-1 Inhibition & SCH 205831 p.0. & Orally & No & $?$ & No & $?$ \\
\hline \\
$\begin{array}{c}\text { PAR-1 selective } \\
\text { receptor inhibitors }\end{array}$
\end{tabular}

\begin{tabular}{|c|c|c|c|c|c|}
\hline \multirow{2}{*}{$\begin{array}{l}\text { vWF antagonists } \\
\text { (humanized } \\
\text { monoclonal antibody } \\
\text { to Vwf) }\end{array}$} & $\begin{array}{l}\text { Inhibition of high- } \\
\text { shearstress-induced } \\
\text { platelet aggregation } \\
\text { in a concentration } \\
\text { dependent manner }\end{array}$ & $\begin{array}{l}\text { AJW200 lgG4 } \\
\text { humanized } \\
\text { monoclonal antibody } \\
\text { to human vWF } \\
\text { derived from Sp2/0 } \\
\text { mouse myeloma } \\
\text { cells. }\end{array}$ & 24 hours & 12 hours & \\
\hline & $\begin{array}{l}\text { Binds with high } \\
\text { afbnity to the } \\
\text { activated vWF A1- } \\
\text { domain and inhibits } \\
\text { VWF dependent } \\
\text { platelet aggregation } \\
\text { through preventing } \\
\text { Gp-lb receptor to } \\
\text { interact with } \\
\text { Willebrand factor }\end{array}$ & $\begin{array}{c}\text { ARC1779 } \\
\text { second-generation, } \\
\text { nuclease resistant } \\
\text { aptamer, which has } \\
\text { been conjugated to a } \\
\text { 20-kDA } \\
\text { polyethylene glyco }\end{array}$ & $1-2$ hours & 2 hours & $8-12$ hours \\
\hline
\end{tabular}

\section{Prasugrel (Efient $\left.{ }^{\circledR}\right)$}

Prasugrel is a third generation thienopyridine, which acts as a selective and irreversible inhibitor of the P2Y12 receptor. Prasugrelexhibits a more rapid antiplatelet effect ex vivo compared with clopidogrel owing to its faster metabolic activation.

Pharmacokinetics/pharmacodynamics.Prasugrel is an oral prodrug that requires conversion into an active metabolite (R-138727) by the hepatic cytochrome P450 (CYP) system. Prasugrel is transformed through hydrolyzation of esterases into the thiolactone,

R-95913 and then further metabolized via oxidation of intestinal and hepatic CYP450 into active metabolite R-138727 [6]. The active metabolite of prasugrel appears rapidly in the blood after ingestion, showing a significant effect after 15 min with a median time to reach a $20 \%$ inhibition of platelet aggregation 30 min after administration [7]. Inhibition of platelet aggregation reaches a steady-state after 2-4 days [6]. Prasugrel's metabolites are eliminated with a median halflife ranging from 3 to $9 \mathrm{~h}$. Two-thirds of metabolites are excreted in the urine, one-third in feces [7].

\section{Ticagrelor(Brilique $\left.{ }^{\mathrm{TM}}, \mathrm{AZD6140}\right)$}

Ticagrelor is an adenosine triphosphate analogue, which belongs to new chemical class cyclopentyltriazolo-pyrimidines. It is the first reversibly binding oral ADP receptor P2Y12 antagonist, which is highly selective for the receptor.

Pharmacokinetics/pharmacodynamics. Ticagrelor' sactive form does not need the metabolic activation required with thienopyridines. Ticagrelor targets the P2Y12 receptor via a mechanism that is non-competitive with ADP, suggesting the existence of a binding site on P2Y12 independent to that of ADP. Thus, ticagrelor may act through an allosteric mechanism preventing G-protein-mediated signal transduction following ADP binding to P2Y12 [8].

Ticagrelor is administered twice a dayorally. It is rapidly absorbed in the small intestine, and its plasma half-life occurs between 1.5 and 3 hours after administration with a steady-state concentration after 2 to 3 days. Ticagrelor is eliminated through the gastrointestinal tract, with less than $1 \%$ through the urine, suggesting that renal dose adjustment is not necessary.

Ticagrelor is metabolized in the liver primarily through CYP3A4/5 isoenzymes. Some of the ticagrelor metabolites exhibit antiplatelet activity. One of them, ARC 124910XX, is present at approximately one-third of the 
plasma concentration of ticagrelor and has a half-life of 8-12 hours. Following cessation, the antiplatelet effects of ticagrelor decline rapidly over $72 \mathrm{~h}$ and normal platelet reactivity is achieved after approximately 5 days [4].

Concomitant use of CYP3A4 inhibitors such as ketoconazole, diltiazem, ritonavir, and clarithromycin or inducers (rifampicin, phenytoin, carbamazepine, and dexamethasone) can prolong the plasma half-life of ticagrelor, so it should be avoided [9].

\section{Cangrelor}

Cangrelor is a reversible, short-acting, potent, competitive P2Y12 inhibitor that has the advantage of being an active drug not requiring metabolic conversion, although it is not orally available.

Pharmacokinetics/pharmacodynamics. With a plasma half-life of 3-9 min, cangrelor after intravenous administration achieves a high level of platelet inhibition within 5 min and reaches steady state concentration within 15-30 min. of administration. Cangrelor is not a prodrug, it is administered in an active form, and it is metabolized in the plasma by dephosphorylation to its nucleoside, which is inactive. In contrast to clopidogrel and prasugrel, cangrelor is rapidly reversible [10]. The combination of the very short half-life and reversible binding underlie the rapid recovery of platelet function in 1-2 hours following the termination of intravenous infusion of cangrelor. The onset of action of clopidogrel and prasugrel is delayed when co-administrated with cangrelor, demonstrating that cangrelor favourably binds to the P2Y12 receptor and prevents the inhibition of prasugrel's or clopidogrel's metabolite [4].

Integrin áIIbâ3 (GPIIb / IIIa) receptor antagonists Expression of the functionally active integrin álIbâ3 (GPIIb/IIIa)on the platelet surface is the final stage of platelet aggregation, making it the subject of development for new antiplatelet drugs [10]. In the mid-70s, Nurden and Caen in France, and Phillips in the U.S.A. found deficiencies of two different platelet membrane glycoproteins in several tribes with Glanzmann thrombasthenia. They have been defined as glycoproteins GPIIb and GPIIIa, existing as a Ca-dependent complex (GPIIb/ IIIa) on the surface of the platelets.

Following recognition that the expression of functionally active integrin aIIbb3 (GPIIb/IIIa)on the platelet surface is the final common pathway of platelet aggregation, this glycoprotein became the target of novel antiplatelet drugs [11].

Correlation of all these findings suggested that blockade of GPIIb/IIIa receptors could be a particularly desirable therapeutic strategy because, firstly, the monoclonal antibodies to GPIIb/IIIa are more potent inhibitors of platelet function than aspirin; secondly, GPIIb/ IIIa is platelet-specific; thirdly, inhibition of GPIIb/IIIa still leaves platelet adhesion largely intact, contributing to haemostasis without causing thrombotic damage; and fourthly, the haemorrhagic diathesis produced by the in- herited deficiency of GPIIb/IIIa receptors in Glanzmann thrombasthenia only rarely produces spontaneous brain haemorrhage, the most feared complication of anticoagulant and antiplatelet therapy.

The success of blockade of GPII / IIIa platelet receptors with intravenous agents (abciximab, eptifibatide, tirofiban) leads to the development of several oral GPIIb/IIIaantagonists [10]. Unfortunately, the oral inhibitors are not clinically effective due to their low bioavailability that leads to a large peak-trough difference and to drug-induced conformational changes in GPIIb / IIIa and possible pharmacogenomics effects in response to the drugs, in particular, the PIA polymorphism in GPIIb / IIIa. The other novel platelet inhibitors are currently in advanced clinical testing [12].

\section{Routine monitoring}

Platelet function testing was initially designed for identification of platelets function disorders. Later, in detecting the role of platelets in the development of atherothrombosis, these tests become useful for monitoring of the antiplatelet drug therapy [13].

Numerous platelet function tests are available (e.g. turbidometric light transmittance, Verify Now, Thrombelastogram, Multiplate, Platelet Function Analyser-100). Currently laboratory control of the antiplatelet therapy is not widely applied in the clinical practice due to the lack of a standardized drug resistance definition found in some patients and to the lack of a generally accepted test for platelet function testing. In addition, there is controversy in the interpretation of the laboratory results of resistance, as is not clear whether they directly turn into an inadequate biological response with a direct clinical application [14].

\section{Drug-drug interactions}

Membrane transporter proteins such as $\mathrm{P}$ gpcan have important effects on the pharmacokinetics of the drugs. Verapamil, diltiazem, quinidine, dronedarone, carvedilol, captopril and amiodarone are inhibitors of P$\mathrm{gp}$, which also plays an important role in the intestinal efflux of clopidogrel and ticagrelor. Moreover, in vitro studies have indicated that ticagrelor and its active metabolite, AR C124910XX, are inhibitors of the P gp transporter. The activity of carboxylesterases, which play an important role in the biotransformation of many drugs, can be inhibited or induced by drugs such as dexamethasone, phenobarbital, and polycyclic aromatic hydrocarbons [4].

\section{Dental considerations}

Most practical recommendations consider dental procedures as minor interventions associated with a low risk of bleeding and self-limited blood loss that can be managed with local haemostatic agents. According to the Scottish Dental Clinical Effectiveness Programme guidance, dental interventions based on the associated bleeding risks can be divided as: (Table 2.) [15]. 
Table 2. Bleeding risks and dental procedures recommended by the Scottish Dental Clinical Effectiveness Programme [15].

\begin{tabular}{|c|c|c|}
\hline Dental procedures that are unlikely to & \multicolumn{2}{|c|}{ Dental procedures that are likely to cause bleeding } \\
\hline & Low bleeding risk procedures & High bleeding risk procedures \\
\hline $\begin{array}{l}\text { Local anaesthesia by infiltration, } \\
\text { intraligamentary or mental nerve block; }\end{array}$ & \multirow[t]{2}{*}{$\begin{array}{l}\text { Simple extractions (1-3, with re- } \\
\text { stricted wound size); }\end{array}$} & \multirow{2}{*}{$\begin{array}{l}\text { Complex extractions, adjacent } \\
\text { extractions that will cause a large } \\
\text { wound, or more than three extrac- } \\
\text { tions at once; }\end{array}$} \\
\hline $\begin{array}{l}\text { Local anaesthesia by inferior dental block } \\
\text { or other regional nerve blocks; }\end{array}$ & & \\
\hline Basic periodontal examination (BPE); & $\begin{array}{l}\text { Incision and drainage of intraoral } \\
\text { swellings; }\end{array}$ & \multirow{4}{*}{$\begin{array}{l}\text { Flap raising procedures; } \\
\text { Elective surgical extractions; } \\
\text { Periodontal surgery; } \\
\text { Periradicular surgery; } \\
\text { Crown lengthening; } \\
\text { Dental implant surgery; }\end{array}$} \\
\hline $\begin{array}{l}\text { Supragingival removal of plaque, calculus, } \\
\text { and stain; }\end{array}$ & $\begin{array}{l}\text { Detailed six-point full periodontal } \\
\text { examination; }\end{array}$ & \\
\hline $\begin{array}{l}\text { Direct or indirect restorations with } \\
\text { supragingival margins; }\end{array}$ & Root surface instrumentation (RSI); & \\
\hline Endodontics (orthograde); & $\begin{array}{l}\text { Direct or indirect restorations with } \\
\text { subgingival margins. }\end{array}$ & \\
\hline $\begin{array}{l}\text { Impressions and other prosthetic proce- } \\
\text { dures; }\end{array}$ & & Gingival recontouring; \\
\hline $\begin{array}{l}\text { Fitting and adjustment oforthodontic } \\
\text { appliances. }\end{array}$ & & Biopsies. \\
\hline
\end{tabular}

Few studies showed that risk of haemorrhage in patients taking direct thrombin inhibitors is similar to those taking warfarin with INR 2 - 3 [16]. For patients requiring simple dental extraction or minor oral surgery as localized periodontal surgery, apical osteotomy, incisional biopsies or excision of a localized mucosal lesion, it can be assumed that the risk is similar to that of patients taking vitamin $\mathrm{k}$ antagonists and with an INR $<3$.

Surgical procedures should be performed as late as possible after the last intake of dabigatran and local haemostatic measures as suturing, gelatine sponge or cellulose mesh, tranexamic acid mouth rinse mast be considered for control of postoperative bleeding $[15,17]$.

Patients who are treated with antiplatelet medications may have additional medical conditions: liver impairment or alcoholism; kidney failure; thrombocytopenia, haemophilia, or other hematologic disorders; treatment with cytotoxic medication that can increase the risk of prolonged bleeding after dental treatment. In these situations, dental practitioners are advised to consult the patient's physician to determine whether care can safely be delivered in a primary care office [17]. Any suggested modification to the medication regimen prior to dental surgery should be done in consultation with and on the advice of the patient's physician $[18,19]$.

\section{Pain control in the postoperative period}

In the postoperative period for pain control Paracetamol is the most suitable choice for patients taking dabigatran. Concomitant treatment of new antiplatelets with NSAIDs may increase the risk of bleeding [19].

\section{NEW ORAL ANTICOAGULANTS}

For more than $80 \mathrm{yr}$, vitamin $\mathrm{K}$ antagonists have been the most frequently prescribed oral anticoagulants. Although highly effective agents they do have numerous limitations: an unpredictable pharmacological profile in different patients, based on genetic factors; multiple foods and drug interactions, and therefore require frequent laboratory monitoring and dose adjustment. They have a slow onset and offset of action and a hypercoagulable state as a result of warfarin-mediated protein $\mathrm{C}$ and $\mathrm{S}$ deficiency that develops in some patients [20]. Therefore, they have a narrow therapeutic window, the risk of stroke and systemic embolism increases with lower levels of anticoagulation (INR <2.0) and bleeding risk is higher when the INR is above 3.0. VKAs have a long half-life and a slow onset of action requiring binding therapy, and after cessation, the drug is eliminated from the plasma slowly for 3-5 days [21]. All this leads to the search for new molecules and the discovery of the direct anticoagulants (Table 3): factor Xa inhibitors and direct thrombin inhibitors. Unlike vitamin $\mathrm{K}$ antagonists, they do not require frequent monitoring, are administered orally and act on specific and single purposes of the coagulation cascade. They have a wide therapeutic margin, low drug- to- drug interactions and no significant food interactions [22, 23]. Their limitations are the lack of effective antidote, high cost and limitations in patients with kidney disease. Prior to surgery, discontinuation of their intake depends on creatinine clearance for 12-120 hours [24]. 
Table 3. Anticoagulant drugs

\begin{tabular}{|c|c|c|c|c|c|c|c|}
\hline Class & $\begin{array}{l}\text { Mechanism } \\
\text { of action }\end{array}$ & Drug & $\begin{array}{l}\text { Time to reach } \\
\text { peak plasma } \\
\text { concentration }\end{array}$ & $\begin{array}{c}\text { Route of } \\
\text { administration }\end{array}$ & $\begin{array}{l}\text { Route of } \\
\text { elimination }\end{array}$ & $\begin{array}{l}\text { Elimination } \\
\text { half-life }\end{array}$ & $\begin{array}{c}\text { Drug } \\
\text { detection } \\
\text { tests }\end{array}$ \\
\hline \multirow{6}{*}{$\begin{array}{l}\text { Coumarin } \\
\text { derivatives }\end{array}$} & Indirect action & Acenocoumarol & $60-120 \mathrm{~min}$ & Per os & Liver & 8-11 hours & INR \\
\hline & Indirect action & Warfarin sodium & $1-1,30$ hours & Per os & Liver & $36-42$ hours & INR \\
\hline & 1,3-Indanediones & Chlorindione & & & & & \\
\hline & 1,3-Indanediones & Diphenindione & & & & & \\
\hline & 1,3-Indanediones & Phenindione & & & & $5-10$ hours & \\
\hline & Others & Thioclomarol & & & & & \\
\hline \multirow[t]{13}{*}{$\begin{array}{c}\text { Factor Xa } \\
\text { inhibitors }\end{array}$} & $\begin{array}{c}\text { second-generation } \\
\text { low molecular } \\
\text { weight heparin }\end{array}$ & Bemiparin & & S.c. & & 5.3 hours & $\begin{array}{l}\text { Heparin } \\
\text { Anti-Xa }\end{array}$ \\
\hline & $\begin{array}{c}\text { Heparin group/ } \\
\text { glycosamino- } \\
\text { glycans/ }\end{array}$ & Certoparin & & S.C. & & & \\
\hline & & Dalteparin & & s.c., i.v. & Renal & $\begin{array}{l}\text { 3-5 hours s.c } \\
2,1-2,3 \text { hi.v. }\end{array}$ & \\
\hline & & Enoxaparin & & s.c., i.v. & $\begin{array}{c}\text { Liver into low } \\
\text { molecular weight } \\
\text { species by either or } \\
\text { both desulfation and } \\
\text { depolymerization }\end{array}$ & 4.5 hours & \\
\hline & & $\begin{array}{l}\text { Nadroparin } \\
\text { (Fraxiparine) } \\
\end{array}$ & $3-5$ hours & $\begin{array}{l}\text { SC (except for } \\
\text { haemodialysis) }\end{array}$ & Renal & $\begin{array}{l}3,5 \text { hours } \\
\text { (SC dose) }\end{array}$ & \\
\hline & & Parnaparin & $2-4$ hours & S.c. & Renal & & \\
\hline & & Reviparin & & & Renal & & \\
\hline & $\begin{array}{c}90 \% \text { for Anti-Xa } \\
\text { activity, } 67 \% \text { for } \\
\text { Anti-lla activit }\end{array}$ & Tinzaparin & & & $\begin{array}{l}\text { Minor metabolisation } \\
\text { in liver by desulfation } \\
\text { and/or depolymerization; } \\
\text { excretion via kidneys in } \\
\text { almost unchanged form }\end{array}$ & $\begin{array}{l}200 \text { min. for } \\
\text { Anti-Xa activity, } \\
\text { 257. min for } \\
\text { Anti-lla activity }\end{array}$ & \\
\hline & & Fondaparinux & & & $\begin{array}{c}\text { Renally excreted } \\
\text { unchanged }\end{array}$ & $17-21$ hours & \\
\hline & & Idraparinux & & & Renal & & \\
\hline & & Danaparoid sodium & & & Renal & & \\
\hline & & Dermatan sulfate & & & Renal & & \\
\hline & & Sulodexide & & & Renal & & \\
\hline $\begin{array}{l}\text { Factor Xa } \\
\text { inhibitors }\end{array}$ & $\begin{array}{c}\text { Direct Reversible } \\
\text { Xa Inhibitor }\end{array}$ & $\begin{array}{l}\text { Apixaban } \\
\text { (Elequis } ®)\end{array}$ & 3-4 hours & $\begin{array}{c}\text { Per os } \\
\text { twise daily }\end{array}$ & $\begin{array}{c}25 \% \text { renal, } \\
55 \% \text { intestinal, } \\
\text { remnant hepatic }\end{array}$ & $9-12$ hours & $\begin{array}{l}\mathrm{PT} \text {, anti } \mathrm{Xa} \\
\text { testing }\end{array}$ \\
\hline $\begin{array}{l}\text { Factor Xa } \\
\text { inhibitors }\end{array}$ & $\begin{array}{l}\text { Direct Xa } \\
\text { Inhibitors }\end{array}$ & Betrixaban & 3-4 hours & $\begin{array}{c}\text { Per os } \\
\text { onse daily }\end{array}$ & Liver & 20 hours & \\
\hline $\begin{array}{l}\text { Factor Xa } \\
\text { inhibitors }\end{array}$ & $\begin{array}{l}\text { Direct Xa } \\
\text { Inhibitors }\end{array}$ & Edoxaban & $1-2$ hours & $\begin{array}{l}\text { Renal elimi- } \\
\text { nation } 50 \% \text {, } \\
\text { not recommen- } \\
\text { ded if e GFR } \\
<30 \mathrm{~mL} / \mathrm{min}\end{array}$ & $\begin{array}{l}\text { Metabolized in the } \\
\text { biliary-fecal system } \\
\text { in about } 65 \% \text { and } \\
\text { is mainly excreted } \\
\text { by the kidneys }\end{array}$ & 6-11 hours & $\begin{array}{l}\text { PT, anti Xa } \\
\text { testing }\end{array}$ \\
\hline $\begin{array}{l}\text { Factor Xa } \\
\text { inhibitors }\end{array}$ & $\begin{array}{l}\text { Direct Xa } \\
\text { Inhibitors }\end{array}$ & Otamyxaban & & & & & \\
\hline $\begin{array}{l}\text { Factor Xa } \\
\text { inhibitors }\end{array}$ & $\begin{array}{l}\text { Direct Xa } \\
\text { Inhibitors }\end{array}$ & $\begin{array}{l}\text { Rivaroxaban } \\
\text { (Xarelto } 囚)\end{array}$ & $2,5-4$ hours & $\begin{array}{l}\text { Per os onse } \\
\text { or twise daily }\end{array}$ & $\begin{array}{c}66 \% \text { renal, } \\
28 \% \text { in feces }\end{array}$ & $\begin{array}{c}5-10 \mathrm{~h} ; \\
12-13 \mathrm{~h} \text { in } \\
\text { patients }>75 \\
\text { years }\end{array}$ & $\begin{array}{l}\text { PT, anti Xa } \\
\text { testing }\end{array}$ \\
\hline $\begin{array}{l}\text { Factor Xa } \\
\text { inhibitors }\end{array}$ & Bivalent & Hirudine i.v. & i.v. & & Kidneys & $\begin{array}{c}\text { i.v. } 40 \mathrm{~min} \\
\text { s.c. } 150-240 \mathrm{~min}\end{array}$ & \\
\hline
\end{tabular}




\begin{tabular}{|c|c|c|c|c|c|c|c|}
\hline $\begin{array}{l}\text { Factor Xa } \\
\text { inhibitors }\end{array}$ & Bivalent & $\begin{array}{c}\text { Bivalirudin } \\
\text { i.v. }\end{array}$ & i.v. & & $\begin{array}{l}\text { Combination of } \\
\text { renal mechanisms } \\
\text { and proteolytic } \\
\text { cleavage }\end{array}$ & $\begin{array}{l}\sim 25 \text { minutes in } \\
\text { patients with } \\
\text { normal renal } \\
\text { function }\end{array}$ & \\
\hline $\begin{array}{l}\text { Direct thrombin } \\
\text { (F II) inhibitors }\end{array}$ & Monovalent & Argatroban & 1 hour & & Renal & $45 \mathrm{~min}$ & \\
\hline $\begin{array}{l}\text { Direct thrombin } \\
\text { (F II) inhibitors }\end{array}$ & Monovalent & $\begin{array}{c}\text { Dabigatran } \\
\text { (Pradaxa®) }\end{array}$ & $2-4$ hours & & $\begin{array}{c}80 \% \text { renal, } \\
20 \% \text { hepatic } \\
\text { Not recommended } \\
\text { if eGFR }<60 \mathrm{~mL} / \mathrm{min} \text {; } \\
\text { contraindicated if } \\
\text { eGFR } 30 \mathrm{~mL} / \mathrm{min} \text {; } \\
\text { renal elimination } 80 \%\end{array}$ & $\begin{array}{l}12-14 \mathrm{~h} \text {; } \\
14-17 \mathrm{~h} \text { in } \\
\text { elderly; } 15-18 \mathrm{~h} \\
\text { in moderate renal } \\
\text { impairment; up to } \\
28 \mathrm{~h} \text { in advanced } \\
\text { renal impairment }\end{array}$ & $\begin{array}{l}\text { aPTT, TT, } \\
\text { ecarincloting } \\
\text { time }\end{array}$ \\
\hline $\begin{array}{l}\text { Direct thrombin } \\
\text { (F II) inhibitors }\end{array}$ & Monovalent & Melagatran i.v. & & No & Renal $(80 \%)$ & $\begin{array}{l}1.5-2 \text { hours in } \\
\text { young, healthy } \\
\text { people, up to } 4-5 \\
\text { hours in } 70-y e a r- \\
\text { old patients }\end{array}$ & $\begin{array}{l}\text { aPTT, PT, TT, } \\
\text { OCT assay }\end{array}$ \\
\hline $\begin{array}{l}\text { Direct thrombin } \\
\text { (F II) inhibitors }\end{array}$ & Monovalent & $\begin{array}{l}\text { Ximelagatran } \\
\text { p.o. }\end{array}$ & $1,5-2,5 \mathrm{~h}$ & Melagatran & Renal (80\%) & 3-5 hours & $\begin{array}{l}\text { aPTT, PT, TT, } \\
\text { OCT assay }\end{array}$ \\
\hline
\end{tabular}

\section{New oral anticoagulants}

In 2004, Ximelagatran was licensed by the European Medical Agency, thus becoming the first oral thrombin inhibitor on the market. As a result of potential hepatotoxicity, it was withdrawn soon after [25]. Since 2008, further new oral anticoagulants have been introduced. These include the direct thrombin inhibitor, dabigatran, and the direct factor $\mathrm{X}$ inhibitors, such as rivaroxaban, apixaban, and edoxaban. Other new oral anticoagulants (NOACs) are currently being tested in clinical trials.

\section{Dabigatran (Pradaxa $\left.{ }^{\circledR}\right)$}

Dabigatran etexilate (Pradaxa ${ }^{\circledR}$, Boehringer Ingelheim, Spain) is the first orally administered direct thrombin inhibitor. It was the first approved NOA in 2008 by the EU and in 2010 by the Food and Drug Administration (FDA).

Pharmacokinetics/pharmacodynamics. Dabigatran is taken twice daily. It is a specific, reversible direct thrombin inhibitor that, after oral administration, is rapidly absorbed and converted to its active form, through esterase catalysed hydrolysis in the plasma. Mechanism of action of dabigatran is to bind with the active site on free and clot-bound thrombin (factor IIa), so it cannot transform fibrinogen into fibrin. It has a rapid onset of action with a peak plasma concentration at $0.5-4 \mathrm{~h}$. Twenty percent of the absorbed drug undergoes hepatic metabolism, while $80 \%$ is excreted unchanged via the renal system, and the dosage must be reduced in patients with renal impairment (Creatinine Clearance $(\mathrm{CrCl})<50 \mathrm{ml} /$ $\min$ ). The half-life elimination is determined by renal function and in healthy patients is $12-14 \mathrm{~h}, 14-17 \mathrm{~h}$ in elderly, up to 18 hours in patients with CrCL between 30 and $50 \mathrm{ml} / \mathrm{min}$ and up to $28 \mathrm{~h}$ in advanced renal impairment (creatinine clearance $<15-30 \mathrm{ml} / \mathrm{min}$ ). Creatinine levels should also be considered even the medication is discontinued before a surgical procedure [26].

\section{Apixaban(Elequis $\circledR$ )}

Apixaban is the most recently introduced direct anticoagulant. Apixaban (Eliquis) is taken twice a day. It is a reversible orally administered FXainhibitor with the same therapeutic indications of dabigatran and rivaroxaban.

Pharmacokinetics/pharmacodynamics. After oral administration, the peak plasma concentration is reached in 1-3 $\mathrm{h}$ with a bioavailability of approximately $60 \%$. The half-life of the drug is about $12 \mathrm{~h}$, and it is excreted almost totally in bile. As rivaroxaban, no specific reversal agent exists for apixaban. In case of emergency situations, recombinant factor VIIa, recombinant factor Xa or activated thrombin complexes can be used. However, few data are available for a correct management of apixaban in case of haemorrhage, and further studies are needed in this respect [27].

\section{Rivaroxaban(Xarelto®)}

Rivaroxaban is an oral selective, reversible direct FXa inhibitor that binds with the part of factor XaIthat catalyses the activation of prothrombin (factor II).

Pharmacokinetics/pharmacodynamics. Rivaroxaban is most commonly taken once a day, either in the morning or at night. It can inhibit free factor Xa but also clot bound factor Xa, and factor Xa bound to the prothrombinase complex. The drug reaches the peak plasma concentration in 2.5-4 h after oral administration. The half-life is 5.7-9.2 $\mathrm{h}$ (up to $12-13 \mathrm{~h}$ in patients older than 75 years) Elimination is $66 \%$ renal and $28 \%$ in feces [28].

\section{Edoxaban}

Edoxaban is a direct, highly selective and competitive inhibitor of factor $\mathrm{Xa}$. It is indicated for the prevention of stroke/systemic embolism in atrial fibrillation (AF) and for the treatment of venous thromboembolism (VTE).

Pharmacokinetics/pharmacodynamics. It has a bioavailability of $62 \%$. Co-administration of strong Pglycoprotein inhibitors (e.g. ketoconazole, amiodarone, 
verapamil, or quinidine) causes an increased effect of edoxaban, necessitating a dose reduction of 50\%. Dose adjustment should be made in patients with moderate renal impairment [29].

\section{Routine monitoring}

Routine monitoring of the anticoagulant effect of NOA is not required. In the emergency situation, the thrombin clotting time (TT) and the ecarin clotting time (ECT) are the most sensitive tests for measuring the anticoagulation rate. Activated partial thromboplastin time (aPTT) is less sensitive, but also can be used in case of emergency. [24, 26, 30, 31].FXaIs, including rivaroxaban, slightly prolong prothrombin time (PT) and aPTT. No routine monitoring of rivaroxaban is generally required; however, in case of an emergency,anti-factor $\mathrm{Xa}$ is reported as the most accurate measurement of anticoagulation[28].

In October 2015, the U.S. Food and Drug Administration approved antidote of dabigatran Idarucizumab, a monoclonal antibody (Praxbind $\AA$, BoehringerIngelheim Pharmaceuticals, Inc., Germany) for the treatment of patients on dabigatran etexilate when reversal of the anticoagulant effect is needed for emergency surgery/urgent procedures, or in life-threatening or uncontrolled bleeding. For minutes Idarucizumab completely reverses the anticoagulant activity of dabigatran in 88 to $98 \%$ of patients [32].

\section{Drug-drug interactions}

Dabigatran has few clinically significant drug and food interactions. Concomitant intake of Ketoconazole, amiodarone and verapamil may increase the anticoagulant effect of dabigatran, whilst rifampicin may decrease its effect. The risk of bleeding may alsobe increased by concomitant use of other anticoagulants, antiplatelets, non-cox-selective NSAIDs and salicylates. Paracetamol and opioid analgesics are appropriate alternatives for pain management [33].

Drug-drug interactions affecting the pharmacokinetics of rivaroxaban Co-administration of apixabanand rivaroxaban with the strong CYP3A4 (e.g. phenytoin, carbamazepine, phenobarbital, rifampicin) leads to over $50 \%$ decrease of plasma concentration of the drugs. P-gp inhibitors, such as Ketoconazole and ritonavir, may increase dramatically plasma concentrations of apixaban $[33,34]$.

Concomitant treatment with edoxabanis contraindicated in subjects receiving ritonavir, cyclosporine, erythromycin, azithromycin, clarithromycin, ketoconazole, itraconazole because these drugs increase its steady-state plasma concentrations [29].

\section{Dental considerations}

The major concern in the treatment of patients taking DOACs is the risk of haemorrhage in dental surgical procedures. Depending on the type of dental procedure and the medical condition of the patient, the risk of bleeding should be considered with the risk of thrombo-embolic complications.
Several treatment approaches can be considered: continue DOACs, time dental treatment as late as possible after the last DOACs dose, discontinue DOACs for $24 \mathrm{hrs}$, or discontinue DOACs for $48 \mathrm{hrs}$ [35].

Patients taking NOAC who requires a dental procedure with low bleeding risk, treatment should be made without interrupting of the anticoagulant medication.

Patients, who are taking NOAC and requires a dental procedure with higher bleeding risk, should omit (apixaban, dabigatran) or delay (rivaroxaban) their morning dose on the day of their dental treatment. If the patient takes rivaroxaban once daily in the evening, there is no need for modification of the intake, as long as at least 4 hours are past after the dental treatment [15].

\section{In addition:}

Treatment preferably should be planned early in the day to allow monitoring and management of bleeding complications. Surgical trauma should be minimized over separate visits, and more complex cases should be referred to a more experienced dentist or an oral surgeon. Local haemostatic measures as gelatine sponge and wound suturing should be used to achieve haemostasis.

Advise the patient on the next drug intake: For rivaroxaban (taken once a day), the delayed morning dose may be taken 4 hours after haemostasis has been achieved. The next dose should be taken as usual the following morning. If the patient normally takes their rivaroxaban in the evening, they can take this at the usual time as no earlier than 4 hours after haemostasis has been achieved.

For apixaban or dabigatran (taken twice a day), having missed the morning dose, the patient should take their evening dose at the usual time as long as no earlier than 4 hours after haemostasis has been achieved.

Advise the patient to contact the practice for advice if bleeding occurs prior to, or after, restarting their NOAC.

The patient should avoid missing subsequent doses of their NOAC unless absolutely required in an emergency situation to control bleeding [15].

Unlike warfarin, where the dose can be adjusted according to the INR, the new drugs are prescribed at fixed doses. Depending on the pharmacokinetics of the drug, patients with impaired liver (alcohol dependence, chronic viral or autoimmune hepatitis, primary biliary cirrhosis) or renal function (Table 4), with a myelodysplastic disorder, haematological malignancy or other bleeding disorders (Willebrand's disease, haemophilia, idiopathic thrombocytopenic purpura) and patients on chemotherapy may have a higher risk of bleeding following an invasive dental procedure. These patients should be referred to an oral and maxillofacial surgeon, especially when the required extractions are complex, extensive or have a high risk of postoperative bleeding [36]. The French Working Group on Perioperative Hemostasis and the French Study Group on Thrombosis and Hemostasis suggests extended interruption of treatment prior to interventions with a high risk of bleeding. [30] (Table 4). 
Table 4. Recommendations on the interval between last dose of direct or non-vitamin-K-dependent oral anticoagulant and intervention/procedure depending on bleeding risk and renal function* [30]

\begin{tabular}{|l|c|c|c|c|}
\hline & \multicolumn{2}{|c|}{ Apixaban/edoxaban/rivaroxaban } & \multicolumn{2}{c|}{ Dabigatran } \\
\hline $\begin{array}{l}\text { Renal function } \\
(\text { CrCl } \mathbf{~} L / \text { min) }\end{array}$ & $\begin{array}{c}\text { Low } \\
\text { Bleeding } \\
\text { risk }\end{array}$ & $\begin{array}{c}\text { High } \\
\text { bleeding } \\
\text { risk }\end{array}$ & $\begin{array}{c}\text { Low } \\
\text { bleeding } \\
\text { risk }\end{array}$ & $\begin{array}{c}\text { High } \\
\text { Bleeding } \\
\text { risk }\end{array}$ \\
\hline$\geq 80$ & $\geq 24 \mathrm{~h}$ & $\geq 48 \mathrm{~h}$ & $\geq 24 \mathrm{~h}$ & $\geq 48\left(-72^{*}\right) \mathrm{h}$ \\
\hline $50-79$ & $\geq 24 \mathrm{~h}$ & $\geq 48\left(-72^{*}\right) \mathrm{h}$ & $\geq 36 \mathrm{~h}$ & $\geq 72\left(-96^{*}\right) \mathrm{h}$ \\
\hline $30-49$ & $\geq 24 \mathrm{~h}$ & $\geq 48\left(\geq 72-96^{*}\right) \mathrm{h}$ & $\geq 48 \mathrm{~h}$ & $\geq 96 \mathrm{~h}$ \\
\hline $15-29$ & $\geq 36 \mathrm{~h}$ & $\geq 48\left(\geq 96^{*}\right) \mathrm{h}$ & No indication for DOACs! \\
\hline$<15$ & \multicolumn{2}{|c|}{ No indication for DOACs! } \\
\hline
\end{tabular}

\section{Pain control in the postoperative period}

Concomitant treatment of NOA with NSAIDs may increase the risk of bleeding.

Paracetamol or opioid medications are safer alternatives for pain control. [18] Dabigatran acts as a substrate of P-glycoprotein 1 (P-gp 1), a significant protein of the cell membrane that pumps many foreign substances out of cells. The concomitant assumption of strong P-gp 1 inducers like dexamethasone, rifampicin or carbamazepine, has been reported to significantly decrease the plasma concentration and peak serum concentration of dabigatran. Hence, these drugs are not recommended in patients taking DTIs. The administration of Pgp 1 inhibitors like ketoconazole (and possibly itraconazole, erythromycin, clarithromycin) should be avoided [34].

\section{DISCUSSION}

Millions of people worldwide are taking haemostasis altering medications, and the need of teeth extraction requires a special approach. Routine practice in the past was the discontinuation of the therapy prior to dental extraction. Nowadays, discontinuation of oral antiplatelet and anticoagulant drugs is not recommended because the risk of severe thromboembolic complications outweighs the risk of bleeding. With the introduction of the new P2Y12 inhibitors (prasugrel, ticagrelor, cangrelor) and the direct oral anticoagulants (dabigatran, rivaroxaban, and apixaban) the dental practitioners are facing an obscure risk of bleeding during oral surgical procedures. In the existing literature, there are not yet a sufficient number of studies defining a clear protocol for dental management in concomitant use of these drugs.

In a review by Muñoz-Corcuera et al. the authors suggest that each case should be treated individually, taking into consideration the risk of embolism, bleeding and renal function [26]. Depending on the risk of bleeding, Curto et al. classified dental treatments in two groups: procedures with low and procedures with medium/high risks of bleeding [37]. Low-risk procedures include simple tooth extractions, oral surgery lasting less than 45 minutes and muco-gingival surgical procedures. The extraction of more than three teeth at once and oral surgery lasting more than 45 minutes were considered medium/ high risk procedures. In this group, the instructions to stop DOACs should be consulted with the specialist physician. The authors suggest that for low risk procedures discontinuation of dabigatran is not necessary, and apixaban can be administered at a usual dose on the day, after the procedure [37].

\section{CONCLUSION}

Currently, available evidence suggests that most dental interventions can be safely performed without the interruption of the antithrombotic therapy. However, further studies are needed to establish evidence-based guidelines for the periprocedural antithrombotic management of patients receiving direct oral anticoagulants or novel antiplatelet agents.

\section{REFERENCES:}

1. Murray CJ, Lopez AD. Alternative Projections of Mortality and Disability by Cause 1990-2020: Global Burden of Disease Study. Lancet. 1997 May 24;349(9064):1498-504. [PubMed] [Crossref]

2. Heit JA. Epidemiology of venous thromboembolism. Nature reviews. Cardiology. 2015 Aug;12(8): 464-474. [PubMed] [Crossref]
3. Kannan M, Ahmad F, Renu Saxena R. Platelet Activation Markers in Evaluation of Thrombotic Risk Factors in Various Clinical Settings. Blood Rev. 2019 Sep;37:100583. [PubMed] [Crossref]

4. Mega JL, T. Simon. Pharmacology of antithrombotic drugs: an assessment of oral antiplatelet and anticoagulant treatments. Lancet, 386
(9990) (2015), pp. 281-291 [PubMed] [Crossref]

5. Sarich TC, Seltzer JH, Berkowitz CD, Costin J, Curnutte JT, Michael Gibson C, et al. Novel Oral Anticoagulants and Reversal Agents: Considerations for Clinical Development. Am Heart J. 2015 Jun; 169(6):751-7. [PubMed] [Crossref]

6. Jakubowski JA, Matsushima N, 
Asai F, Naganuma H, Brandt JT, Hirota $\mathrm{T}$ et al. A multiple dose study of prasugrel (CS-747), a novel thienopyridine P2Y12 inhibitor, compared with clopidogrel in healthy humans. Br J ClinPharmacol 2007; 63: 421430. [PubMed] [ Crossref]

7. Umemura K, Iwaki T. The Pharmacokinetics and Pharmacodynamics of Prasugrel and Clopidogrel in Healthy Japanese Volunteers. Clin Pharmacol Drug Dev. 2016;5(6):480_ 487. [PubMed] [Crossref]

8. Martin AC, Zlotnik D, Porta Bonete G, Baron E, Decouture B, Belleville-Rolland T, et al. Epinephrine Restores Platelet Functions Inhibited by Ticagrelor: A Mechanistic Approach. Eur J Pharmacol. 2020 Jan 5;866:172798. [PubMed] [Crossref]

9. Koenig-Oberhuber V, Filipovic M. New antiplatelet drugs and new oral anticoagulants. British Journal of Anaesthesia 2016; 117 (S2): ii74-ii84 [PubMed] [Crossref]

10. Baker DE, Ingram KT. Cangrelor. Hosp Pharm. 2015 Nov; 50(10):922-9 [PubMed] [Crossref]

11. Coller BS. Blockade of Platelet GPIIb/IIIa Receptors as an Antithrombotic Strategy. Circulation. 1995 Nov;92(9):2373-80 [PubMed] [Crossref]

12. Cox D. Oral GPIIb/IIIa Antagonists: What Went Wrong? Curr Pharm Des. 2004; 10(14):1587-96. [PubMed] [Crossref]

13. Gross L, Aradi D, Sibbing D. Platelet Function Testing in Patients on Antiplatelet Medications. Semin Thromb Hemost. 2016 Apr;42(3):30620 [PubMed] [Crossref]

14. Sambu N, Curzen N. Monitoring the effectiveness of antiplatelet therapy: opportunities and limitations. Br J Clin Pharmacol. 2011 Oct; 72(4): 683-696 [PubMed] [Crossref]

15. Management of Dental Patients Taking Anticoagulants or Antiplatelet Drugs. Dental Clinical Guidance. Scottish Dental Clinical Effectiveness Programme (SDCEP). August 2015. [Internet]

16. Healey JS, Eikelboom J, Douketis J, Wallentin L, Oldgren J, Yang $\mathrm{S}$, et al. Periprocedural bleeding and thromboembolic events with dabigatran compared with warfarin: results from the Randomized Evaluation of Long-Term Anticoagulation Therapy (RE-LY) randomized trial. Circulation. 2012 Jul;126(3):343-8 [PubMed] [Crossref]

17. Bajkin BV, Vujkov SB, Milekic BR, Biljana A. Vuckovic BA. Risk factors for bleeding after oral surgery in patients who continued using oral anticoagulant therapy. J Am Dent Assoc. 2015; 146 (6): 375-381 [PubMed] [ $\underline{\text { Crossref] }}$

18. Thean D, Alberghini M. Anticoagulant therapy and its impact on dental patients: a review. Aust Dent J. 2016 Jun;61(2):149-56 [PubMed] [Crossref]

19. Patton LL, Glick M, editors. The ADA Practical Guide to Patients with Medical Conditions. 2nd ed. Hoboken, NJ: John Wiley \& Sons, Inc.; 2016. p. 25-42.

20. Firriolo FJ, Hupp WS. Beyond warfarin: the new generation of oral anticoagulants and their implications for the management of dental patients. Oral Surg Oral Med Oral Pathol Oral Radiol. 2012 Apr; 113(4): 431-41 [PubMed] [Crossref]

21. Ageno W, Gallus AS, Wittkowsky A, Crowther M, Hylek EM, Palareti G. Oral Anticoagulant Therapy. Antithrombotic Therapy and Prevention of Thrombosis. 9th ed: American College of Chest Physicians Evidence-Based Clinical Practice Guidelines. Chest. 2012 Feb; 141(2 Suppl):e44S-e88S [PubMed] [Crossref]

22. Mekaj YH, Mekaj AY, Duci SB, Miftari EI. New oral anticoagulants: their advantages and disadvantages compared with vitamin $\mathrm{K}$ antagonists in the prevention and treatment of patients with thromboembolic events. Ther Clin Risk Manag. 2015 Jun;11:967-77. [PubMed] [Crossref]

23. Baker WL, Johnson SG. Pharmacogenetics and oral antithrombotic drugs. Curr Opin Pharmacol. 2016 Apr;27:38-42 [ubMed] [ Crossref]

24. O'Connell JE, Stassen LFA. New Oral Anticoagulants and Their Implications for Dental Patients. J Ir Dent Assoc. 2014 Jun-Jul;60(3):13743. [PubMed]

25. Keisu M, Andersson TB. Druginduced liver injury in humans: the case of ximelagatran. Handb Exp Pharmacol. 2010;(196):407 418. [PubMed] [Crossref]

26. Muñoz-Corcuera M, RamírezMartínez-Acitores L, López-Pintor RM, Casañas-Gil E, HernándezVallejo G. Dabigatran: A new oral anticoagulant. Guidelines to follow in oral surgery procedures. A systematic review of the literature. Med Oral Patol Oral Cir Bucal. 2016 Nov 1;21(6):e679-e688. [PubMed] [Crossref]

27. Byon W, Sweeney K, Frost C, Boyd RA. Population Pharmacokinetics, Pharmacodynamics, and Exploratory Exposure-Response Analyses of Apixaban in Subjects Treated for Venous Thromboembolism. CPT Pharmacometrics Syst Pharmacol. 2017; 6(5):340-349. [PubMed] [Crossref]

28. Gulilat M, Tang A, Gryn SE, Leong-Sit P, Skanes AC, Alfonsi JE, et al. Interpatient Variation in Rivaroxaban and Apixaban Plasma Concentrations in Routine Care. Can J Cardiol. 2017; 33(8):1036-1043. [PubMed] [Crossref]

29. De Caterina R, Ageno W, Boriani G, Colonna P, Ghirarduzzi A, Patti $\mathrm{G}$ et al. Edoxaban in Atrial Fibrillation and Venous Thromboembolism-Ten Key Questions and Answers: A Practical Guide. AdvTher. 2017; 34(3):620-637. [PubMed] [Crossref]

30. Husted S, Verheugt FWA, Comuth WJ. Reversal Strategies for NOACs: State of Development, Possible Clinical Applications and Future Perspectives. Drug Saf. 2016 Jan; 39(1):5-13. [PubMed] [Crossref]

31. Morimoto Y, Yokoe C, Imai Y, Sugihara M, Futatsuki T. Tooth Extraction in Patients Taking Nonvitamin K Antagonist Oral Anticoagulants. J Dent Sci. 2016 Mar;11(1):5964. [ㅁubMed] [ $\underline{\text { Crossref }}]$

32. Pollack CV, Reilly PA, Eikelboom J, Glund S, Verhamme P, Bernstein RA, et al. Idarucizumab for Dabigatran Reversal. $N$ Engl J Med. 2015 Aug 6;373(6):511-20. [PubMed] [Crossref]

33. Di Minno A, Frigerio B, Spadarella G, Ravani A, Sansaro D, Amato M, et al. Old and new oral anticoagulants: Food, herbal medicines and drug interactions. Blood Rev. 
2017 Jul;31(4):193-203 [PubMed] [Crossref]

34. StöllbergerC. Drug interactions with new oral anticoagulants in elderly patients. Expert Rev Clin Pharmacol. 2017 Nov;10(11):11911202 [PubMed] [Crossref]

35. Elad S, Marshall J Meyerowitz C, Connolly G. Novel
Anticoagulants: General Overview and Practical Considerations for Dental Practitioners. Oral Dis. 2016 Jan; 22(1):23-32. [PubMed] [Crossref]

36. Johnston S. An Evidence Summary of the Management of Patients Taking Direct Oral Anticoagulants (DOACs) Undergoing Dental Surgery. Int J Oral Maxillofac Surg. 2016
May;45(5):618-30. [ [PubMed] [Crossref]

37. Curto A, Albaladejo A, Alvarado A. Dental Management of Patients Taking Novel Oral Anticoagulants (NOAs): Dabigatran. $J$ ClinExp Dent. 2017 Feb 1;9(2):e289e293. [PubMed] [Crossref]

Please cite this article as: Dinkova AS, Daskalov HI, Delev D. Dental considerations in patients taking new antiplatelet and anticoagulant drugs. J of IMAB. 2020 Apr-Jun;26(2):3144-3154. DOI: https://doi.org/10.5272/jimab.2020262.3144

Received: 08/07/2019; Published online: 20/05/2020

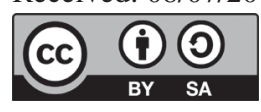

Address for correspondence:

Atanaska Spasova Dinkova DMD, PhD

Oral surgery department, Faculty of dental medicine, Medical University of Plovdiv,

3, HristoBotevblvd., Plovdiv, Bulgaria

E-mail: dinkova_asia@yahoo.com 